\title{
Whitefellas (From the book Walk Back Over)
}

Jeanine Leane

University of Melbourne, Melbourne, Australia 
Walk Back Over alludes to a bridge across the Murrumbidgee River where I grew up but, more symbolically, mirrors the need to revisit our past. Much was made of the 2000 Reconciliation Walk across Sydney Harbour Bridge-many settler Australians walked across this and other bridges, and I am not cynical about that - but there are many other spans in Australia that must be walked: not just once, walked back over.

\section{Whitefellas}

Whitefellas have a license to stare in car parks, foyers, forums and gatherings at anybody else who doesn't look white. They're famous for asking Blackfellas where we come from even though they belong to the oldest diaspora of all.

Whitefellas are experts on Aboriginal affairs and have ready opinions. In particular white men in the academy seem to know a lot about Aboriginal women.

Sometimes Aboriginal people amaze whitefellas if we finish school and go to university. Then we're encouraged to be more like them but whitefellas are surprised if we are too much like them and say; Why do you call yourself an Aborigine when you live just like us?

Whitefellas know Aborigines are good at sport it's all about natural ability and intuition.

But whites succeed through hard work, preparation and structure.

Aboriginal sports people can be a challenge for white coaches because we lack discipline. But white people are happy to say that rugby league has done a lot for Aboriginal people even though Aboriginal people have done a lot for rugby league.

They are happy too that they created sports that Aboriginal people excel at like boxing - then they are happy to call us Australian

Whitefellas hope that the gap in health, education, housing, income and life expectancy between black and white Australians will close soon.

But they still put shopping bags on bus seats between themselves and the nearest Aborigine maybe that space needs to close first.

Perhaps the biggest gap of all is 
across the grey matter between Whitefellas ears when they think of us. Maybe they need to build a bridge or a road to transverse that chasm - because they like building things - don't they - Whitefellas! And when they've built that bridge, they should walk back over it to make sure it's solid - not just tell us that it is because we're over promises.

Whitefellas feel sorry for us because we have 'lost' our culture over time and apparently age doesn't weary theirs. They call change progress.

Whitefellas like to study true Aborigines in the bush and bring their knowledge back to cultureless urban mobs like me - but we're a pain - us urban mobs - too many questions and Whitefellas know that real Aborigines don't ask questions.

If we go to university we should take courses in Aboriginal studies because whitefellas know that with their guidance we'll be good at it maybe we can even help other Aborigines.

Some say that Aborigines don't work in Australia! Truth is Australia doesn't work without Aborigines! This country would be broke without Blackfellas.

Advice is a one-way street in colonial Australia and Whitefellas never seem to tire of that well-worn track.

Excerpted from Walk Back Over. Cordite Books, 2018. Printed with permission.

Jeanine Leane is a Wiradjuri writer, poet and academic from southwest New South Wales. She teaches Creative Writing and Aboriginal Literature at the University of Melbourne. Jeanine is the recipient of an Australian Research Council Fellowship for a project called 'Aboriginal Writing: Shaping the literary and cultural history of Australia, since 1988; and the 2019 recipient of the Red Room Poetry Fellowship, Sydney. 